\title{
INVENTARISASI ZINGIBERACEAE DI KAWASAN HUTAN TEMBAWANG DESA SUMBER KARYA KECAMATAN TERIAK KABUPATEN BENGKAYANG
}

\author{
Veronika Andini $^{*}$, Rafdinal $^{1}$, Masnur Turnip ${ }^{1}$ \\ ${ }^{1}$ Program Studi Biologi, Fakultas Matematika dan Ilmu Pengetahuan Alam, Universitas Tanjungpura \\ Jl. Prof. Dr. H. Hadari Nawawi, Pontianak, Kalimantan Barat \\ *Email: veronikaandini25@gmail.com
}

\begin{abstract}
Zingiberaceae is the family of flowering plants commonly known by the people of Indonesia as the Jahejahean. This plant is widely used for many things such as spices, medicine, ornamental plants, cosmetic ingredients, beverage ingredients, hair tonic, etc. The aim of the study is to know Zingiberaceae species diversity in Tembawang Forest, Sumber Karya Village, Teriak District, Bengkayang City, West Kalimantan. The method of the research used exploration with observation in three Tembawang Forest at Sumber Karya Village. The results showed that there were seven species of Zingiberaceae namely E. coccinea, E. elatior, E. nasuta, G. atrosanguinea, H. reticulata, Z. multibracteatum, and Z. zerumbet.
\end{abstract}

Keywords: Bengkayang, Tembawang forest, Zingiberaceae

\section{PENDAHULUAN}

Zingiberaceae merupakan famili atau suku tumbuhan berbunga yang secara umum dikenal oleh masyarakat Indonesia sebagai jahe-jahean. Zingiberaceae banyak ditemukan pada kawasan hutan tropis. Menurut Pandey (2003), terdapat sekitar $50 \%$ dari total genera famili Zingiberaceae yang ditemukan di hutan tropis. Zingiberaceae dapat hidup dari dataran rendah sampai ketinggian 2000 meter di atas permukaan laut terutama daerah dengan curah hujan yang tinggi. Sejauh ini daerah yang kaya akan jenis-jenis Zingiberaceae adalah wilayah Indonesia, Malaysia, Brunei, Singapura, Thailand, Filipina dan Papua.

Famili Zingiberaceae mempunyai ciri khas pada rhizomnya yang mengandung zat kimia (minyak atsiri). Zingiberaceae dimanfaatkan sebagai bumbu masak, obat-obatan, tanaman hias, bahan kosmetik, bahan minuman, dan sebagainya. Zingiberaceae yang paling banyak dimanfaatkan terdapat pada genera Alpinia, Amomum, Curcuma, Zingiber, Boesenbergia, Kaempferia, Elettaria, Elettariopsis, Etlingera dan Hedychium. Beberapa jenis Curcuma dapat digunakan untuk mengobati gigitan ular dan anti tumor. Kandungan minyak atsiri dalam Zingiber dapat dimanfaatkan sebagai obat dan memiliki aroma yang khas (Larsen et al., 1999).

Kawasan hutan tembawang atau sering disebut sebagai agroforest tembawang. Kawasan hutan tembawang merupakan suatu sistem pengelolaan tanaman hutan yang dikombinasi dengan pertanian. Sistem tembawang merupakan perpaduan tengkawang (pohon buah) dan pohon kayu baik yang berasal dari bekas kampung yang telah ditinggalkan maupun lokasi yang sengaja ditanam pohon buahbuahan (Harum, 2012).

Kawasan hutan tembawang di Desa Sumber Karya Kabupaten Bengkayang terdiri dari tiga hutan tembawang yakni, hutan tembawang Sibo, hutan tembawang Beringin dan hutan tembawang Nameng. Berdasarkan survey yang telah dilakukan pada kawasan tersebut banyak ditemukan jenisjenis Zingiberaceae, namun belum ada data tentang jenis-jenis Zingiberaceae di Kawasan Tembawang Desa Sumber Karya. Berdasarkan hal tersebut maka perlu dilakukan penelitian tentang Inventarisasi Zingiberaceae di Kawasan Hutan Tembawang Desa Sumber Karya, Kecamatan Teriak, Kabupaten Bengkayang. Penelitian ini bertujuan untuk mengetahui jenis-jenis Zingiberaceae dan data hasil penelitian diharapkan dapat dijadikan informasi dasar mengenai jenis Zingiberaceae di Kawasan Hutan Tembawang, Desa Sumber Karya, Kecamatan Teriak, Kabupaten Bengkayang.

\section{BAHAN DAN METODE}

\section{Waktu dan Tempat}

Penelitian ini dilaksanakan selama tiga bulan dari Agustus hingga Oktober 2019. Penelitian dilakukan di Kawasan Hutan Tembawang Desa Sumber Karya Kecamatan Teriak Kabupaten Bengkayang. Identifikasi dan pembuatan herbarium dilakukan di Laboratorium Biologi, FMIPA, Universitas Tanjungpura. 


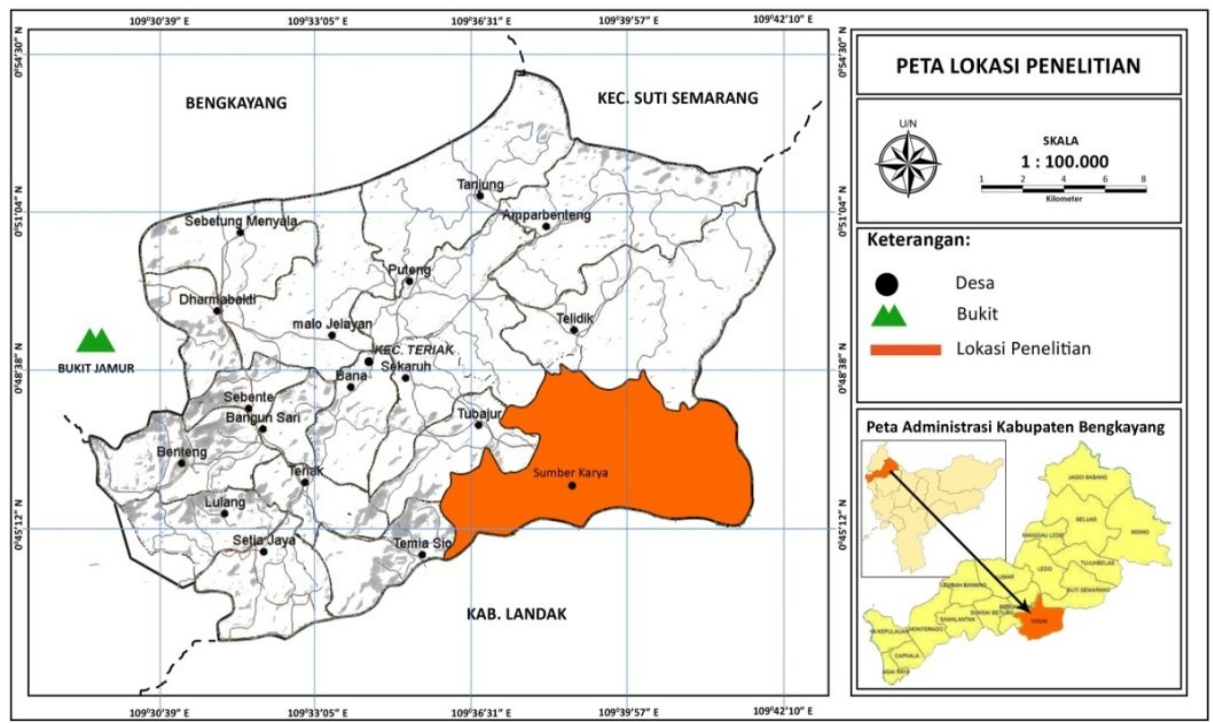

Gambar 1. Peta Lokasi Penelitian

\section{Lokasi Penelitian}

Kawasan Hutan Tembawang Desa Sumber Karya terdapat tiga kawasan tembawang yaitu Kawasan Hutan Tembawang Sibo, Hutan Tembawang Beringin dan Hutan Tembawang Nameng. Desa Sumber Karya secara geografis terletak pada titik koordinat $0^{\circ} 48^{\prime} 42^{\prime \prime}-0^{\circ} 44^{\prime} 35$ " Lintang Utara $109^{\circ} 35^{\prime} 00^{\prime \prime}$ - 109'40'27" Bujur Timur (Gambar 1). Secara administratif Desa Sumber Karya berbatasan dengan wilayah sebagai berikut:

a. Sebelah Utara berbatasan dengan Desa Telidik

b. Sebelah Timur berbatasan dengan Kabupaten Landak

c. Sebelah Selatan berbatasan dengan Kabupaten Landak

d. Sebelah Barat berbatasan dengan Desa Tebajur

\section{Alat dan Bahan}

Alat-alat yang digunakan adalah alat tulis, benang jahit, cangkul kecil, GPS (Global Positioning System), etiket gantung, gunting, jarum jahit, kamera, kardus, kertas label, kertas karton, kertas koran, kertas manila putih, plastik bening, plastik penyimpanan sasak, selotip, sprayer, termometer, tabel karakter stet, dan toples. Bahan-bahan yang digunakan dalam penelitian ini adalah alkohol $70 \%$, spirtus dan tumbuhan Zingiberaceae yang ditemukan. Alat dan bahan selanjutnya yaitu buku identifikasi.

\section{Pengambilan Sampel}

Pengambilan sampel tumbuhan Zingiberaceae dilakukan di Kawasan Tembawang, Desa Sumber Karya, Kabupaten Bengkayang melalui observasi lapangan secara langsung dengan menggunakan metode jelajah (Cruise Method), yaitu dengan menjelajahi setiap sudut lokasi yang dapat mewakili tipe-tipe ekosistem ataupun vegetasi di kawasan yang diteliti (Rugayah et al., 2004). Metode jelajah yang dilakukan yaitu penjelajahan di sepanjang jalur yang disesuaikan dengan keadaan di lapangan. Pengambilan contoh herbarium pada lokasi penelitian hanya dilakukan sekali untuk setiap jenisnya. Apabila ditemukan jenis yang sama maka hanya dilakukan pendataan pada jenis tersebut.

Pengambilan sampel tumbuhan lengkap terdiri atas daun, batang, bunga (bila ada), buah (bila ada), akar maupun rimpang. Setelah itu dilakukan pencatatan karakter tumbuhan Zingiberaceae ke dalam tabel karakteristik mengenai tanggal pengambilan sampel, nama daerah, habitat, letak rhizome, bau rhizome, warna kulit rhizome, warna sisik rhizome, tinggi batang, permukaan batang, warna daun, bentuk ujung daun, bentuk pangkal daun, pertulangan daun, permukaan daun, warna bunga, bau bunga, letak bunga dan warna buah, dan ciri lain yang akan hilang bila dikeringkan. Selanjutnya dilakukan pengambilan foto pada bagian tanaman yang dianggap penting. Kemudian, sampel dikoleksi dan diberi label. 


\section{Pembuatan Herbarium}

Pembuatan herbarium dilakukan terhadap jenis Zingiberaceae yang belum diketahui jenisnya sedangkan jenis Zingiberaceae yang sudah umum atau sudah diketahui jenisnya, diambil fotonya, dicatat nama ilmiahnya dan nama daerahnya. Pembuatan herbarium kering dilakukan dengan penge-ringan spesimen dan penempelan spesimen. Spesimen berupa daun, batang, akar maupun rimpang, diletakkan di atas kertas koran dan disemprotkan dengan alkohol 70\% hingga basah. Spesimen diatur diantara kertas koran, setiap satu lipatan koran terdapat satu spesimen. Lipatan koran berisi spesimen tersebut ditumpuk jadi satu kemudian ditekan dengan kardus dan sasak, lalu dikeringanginkan (Onrizal, 2005).

Penempelan spesimen yang telah kering, satu persatu diletakan di atas kertas karton atau kertas manila putih, berukuran $30 \mathrm{~cm}$ x $40 \mathrm{~cm}$. Spesimen selanjutnya dijahit rapi, diberi label berisi deskripsi singkat dan dibungkus dengan plastik bening. Karakter spesimen yang diperoleh dicatat pada etiket gantung yang berisi mengenai nomor koleksi, nama kolektor, nama lokal, nama ilmiah, tanggal koleksi, dan deskripsi tumbuhan (Steenis, 2005).

Herbarium basah dilakukan dengan cara mengambil organ tumbuhan yang penting untuk identifikasi seperti bunga dan buah. Organ bunga dan buah dipisahkan lalu dibersihkan. Herbarium basah kemudian dimasukan ke dalam toples yang berisi spirtus atau alkohol $70 \%$ dan diberi keterangan pada bagian luarnya meliputi nomor koleksi, nama kolektor, nama lokal, nama ilmiah, tanggal koleksi, dan deskripsi habitat.

\section{Identifikasi sampel}

Identifikasi sampel tumbuhan Zingiberceae dilakukan dengan mencocokkan karakteristik dan foto sampel. Identifikasi sampel dilakukan setelah pembuatan herbarium, di Laboratorium Biologi, Fakultas Matematika dan Ilmu Pengetahuan Alam Universitas Tanjungpura Pontianak. Identifikasi dengan menggunakan buku identifikasi antara lain: Etlingera of Borneo (Poulsen, 2006) dan A guide to gingers of Borneo (Lamb et al., 2013).

\section{Penyajian Data}

Data yang diperoleh dapat disajikan secara deskriptif dan tabulasi. Data yang disajikan secara deskriptif untuk menjelaskan karakter jenis Zingiberaceae yang ditemukan. Selanjutnya, data yang disajikan dalam bentuk tabulasi untuk menjelaskan karakter jenis Zingiberaceae dalam bentuk tabel.

\section{HASIL DAN PEMBAHASAN}

\section{Hasil}

Berdasarkan hasil penelitian yang telah dilakukan di lapangan pada kawasan hutan tembawang di Desa Sumber Karya ditemukan tujuh spesies Zingiberaceae yang tergolong kedalam empat genus berbeda. Keempat genus tersebut yaitu Etlingera, Globba, Hornstedia, dan Zingiber. Ketujuh spesies dan jumlah spesies yang ditemukan dari setiap lokasi dapat dilihat pada Tabel 1.

Jenis Zingiberaceae yang paling banyak ditemukan adalah dari genus Etlingera yang terdiri dari tiga jenis. Jenis yang paling sedikit ditemukan berasal dari genus Globba dan Hornstedia yang masingmasing hanya ditemukan satu jenis. Zingiberaceae yang ditemukan di kawasan hutan tembawang Desa Sumber Karya sebagaimana tertera pada Tabel 1 yang dari hasil penelitian menunjukkan bahwa spesies yang ditemukan sebanyak empat genus dari tujuh spesies dengan jumlah total individu sebanyak 57 individu.

Tabel 1. Jenis Zingiberaceae di Kawasan Hutan Tembawang Desa Sumber Karya Kecamatan Teriak Kabupaten Bengkayang

\begin{tabular}{|c|c|c|c|c|c|c|}
\hline \multirow{2}{*}{ No } & \multirow{2}{*}{ Genus } & \multirow{2}{*}{ Spesies } & \multicolumn{3}{|c|}{ Tembawang } & \multirow{2}{*}{ Jumlah } \\
\hline & & & Sibo & Beringin & Nameng & \\
\hline \multirow[t]{3}{*}{1.} & Etlingera & Etlingera coccinea & $\sqrt{ }$ & $\sqrt{ }$ & - & 9 \\
\hline & & Etlingera elatior & $\sqrt{ }$ & $\sqrt{ }$ & $\sqrt{ }$ & 6 \\
\hline & & Etlingera nasuta & - & $\sqrt{ }$ & - & 4 \\
\hline 2. & Globba & Globba atrosanguinea & - & $\sqrt{ }$ & - & 3 \\
\hline 3. & Hornstedia & Hornstedia reticulata & $\sqrt{ }$ & $\sqrt{ }$ & $\sqrt{ }$ & 18 \\
\hline \multirow[t]{2}{*}{4.} & Zingiber & Zingiber multibracteatum & - & $\sqrt{ }$ & - & 5 \\
\hline & & Zingiber zerumbet & $\sqrt{ }$ & - & $\sqrt{ }$ & 8 \\
\hline Tota & & & 4 & 6 & 3 & 57 \\
\hline
\end{tabular}

Keterangan: $\sqrt{ }=$ ada ditemukan Zingiberaceae 
Tabel 2. Pengukuran Faktor Lingkungan di Kawasan Hutan Tembawang Desa Sumber Karya Kecamatan Teriak Kabupaten Bengkayang

\begin{tabular}{cccccc}
\hline \multirow{2}{*}{ No } & Lokasi Tembawang & Titik Koordinat & $\begin{array}{c}\text { Ketinggian } \\
(\mathrm{m} \text { dpl })\end{array}$ & Suhu $\left({ }^{0} \mathrm{C}\right)$ & Kelembaban $(\%)$ \\
\hline 1. & Tembawang Sibo & $\begin{array}{l}\mathrm{N}: 0.7213^{0} \\
\mathrm{E}: 109.63205^{0}\end{array}$ & 900 & 26 & 80.3 \\
\hline 2. & Tembawang Beringin & $\begin{array}{l}\mathrm{N}: 0.7717^{0} \\
\mathrm{E}: 109.64007^{0}\end{array}$ & 1100 & 25 & 82.0 \\
\hline 3. & Tembawang Nameng & $\begin{array}{l}\mathrm{N}: 0.75311^{0} \\
\mathrm{E}: 109.62239^{0}\end{array}$ & 500 & 27 & 73.6 \\
\hline
\end{tabular}

Kawasan hutan tembawang di Desa Sumber Karya, Kabupaten Bengkayang memiliki tiga kawasan hutan tembawang, yaitu hutan tembawang Sibo, hutan tembawang Beringin dan hutan tembawang Nameng. Kawasan hutan tembawang Sibo ditemukan empat jenis dari tiga genus yaitu, E. coccinea, E. elatior, H. reticulata, dan Z. zerumbet. Kawasan Hutan Tembawang Beringin yang paling banyak jenisnya, terdiri dari enam jenis dari empat genus, yaitu $E$. coccinea, $E$. elatior, E. nasuta, $H$. reticulata, $G$. atrosanguinea dan Z. multibracteatum. Kawasan Hutan Tembawang Nameng terdiri dari dua jenis dari dua genus yaitu E. elatior dan Z. zerumbet. Hasil pengukuran faktor lingkungan yang telah dilakukan di lapangan pada kawasan hutan tembawang di Desa Sumber Karya dapat dilihat pada Tabel 2.

Lokasi kawasan hutan tembawang di Desa Sumber Karya merupakan hutan pegunungan bawah sampai dengan 1300 meter di atas permukaan laut. Lokasi tembawang yang diteliti terdiri dari tiga lokasi tembawang yaitu, tembawang Sibo, tembawang Beringin, dan tembawang Nameng. Kawasan hutan tembawang tersebut mempunyai faktor lingkungan seperti suhu $25-27^{\circ} \mathrm{C}$ dan kelembaban 73,6-82 \%.

Deskripsi morfologi jenis Zingiberaceae di kawasan Hutan Tembawang Desa Sumber Karya Kecamatan Teriak Kabupaten Bengkayang

Deskripsi jenis Zingiberaceae yang ditemukan di kawasan Hutan Tembawang, Desa Sumber Karya, Kecamatan Teriak, Kabupaten Bengkayang menurut Poulsen (2006) sebagai berikut:

\section{Etlingera coccinea (Blume) S.Sakai \& Nagam.}

E. coccinea yang ditemukan merupakan herba berumpun yang memiliki tinggi tanaman $2 \mathrm{~m}$, rimpang tumbuh menjalar dibawah permukaan tanah, bentuk rimpang berdaging berwarna putih, beraroma tajam. Batang (pseudostem) tegak memanjang secara horizontal, berwarna kekuningan dengan permukaan yang kasap. Daun (lamina) merupakan daun majemuk, tersusun berselang, dengan bentuk memanjang, permukaan atas dan bawah daun licin, pangkal daun meruncing, per-tulangan daun menyirip dan tepi daun rata (Gambar 2a). Bunga (flos) terletak aksilar atau muncul langsung dari rimpang, memiliki tangkai bunga yang pendek. Mahkota bunga (corolla) berbentuk memanjang, warna pangkal merah dengan ujung warna merah, dan warna tepi helaian mahkota bunga (corolla) berwarna kuning (Gambar 2b).

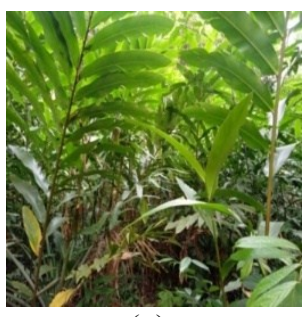

(a)

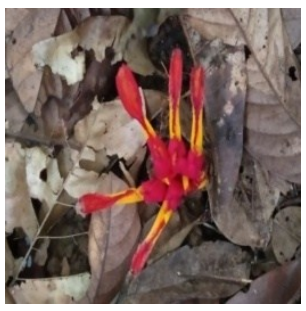

(b)

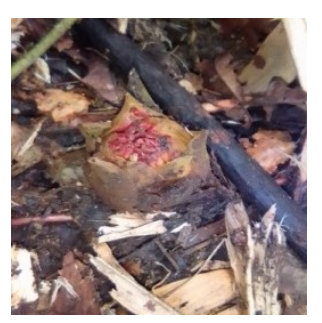

(c)

Gambar 2. Keseluruhan Etlingera coccinea (Blume) (a). Batang dan daun, (b). Bunga, (c). Buah

\section{Etlingera elatior (Jack) R.M.Sm.}

E. elatior memiliki rimpang berkayu, berada di dalam tanah, permukaan rimpang berwarna coklat kemerahan, daging rimpang berwarna putih, dan beraroma tajam. Batang (pseudostem) tegak memanjang secara horizontal, berwarna hijau dan permukaan batang licin. Daun (lamina) merupakan daun majemuk, tersusun berselang berbentuk bulat telur, permukaan atas licin, permukaan bawah kasap, berwarna hijau kekuningan, ujung 
meruncing, pangkal daun membulat, pertulangan daun menyirip, dan tepi daun rata (Gambar 3a). Bunga (flos) muncul langsung dari rimpang, dengan tangkai bunga yang panjang berwarna merah berukuran $30 \mathrm{~cm}$. Kelopak bunga (calyx) berbentuk lanset, permukaan licin, warna pangkal putih, bagian ujung rucing berwarna merah muda dan berbulu halus. Mahkota bunga (corolla) berbentuk lanset, warna pangkal putih dengan ujung warna merah muda. Buah berbentuk kapsul yang berkelompok, berwarna merah (Gambar 3b dan $3 \mathrm{c})$.

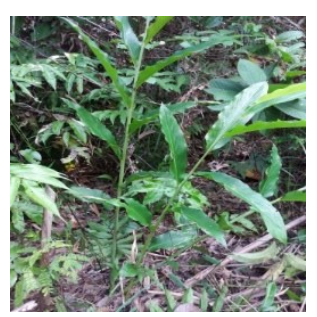

(a)

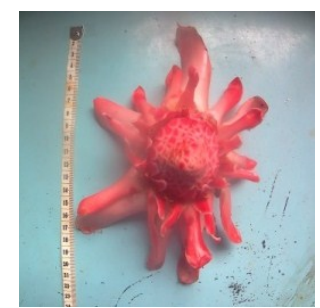

(b)

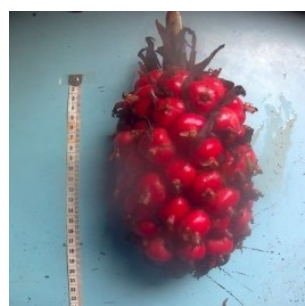

(c)

Gambar 3. Etlingera elatior (Jack) R.M.Sm., (a). Batang dan daun, (b). bunga (c). Buah

\section{Etlingera nasuta (K. Schum.) R.M.Sm.}

E. nasuta memiliki rimpang (rhizome) yang berada di bawah permukaan tanah, bentuk rimpang berdaging, berwarna putih dan beraroma halus. Batang (pseudostem) tumbuh tegak memanjang secara horizontal, berwarna hijau kecoklatan dengan permukaan licin. Daun (lamina) merupakan daun majemuk tunggal berselang, berbentuk lanset, berwarna hijau, permukaan atas dan bawah daun licin, pangkal daun meruncing, pertulangan daun menyirip, dan tepi daun rata (Gambar 4a).

Bunga (flos) terletak aksilar atau muncul langsung dari rimpang, berwarna merah, tidak beraroma. Kelopak bunga (calyx) berbentuk memanjang, permukaan licin, warna pangkal putih, bagian ujung rucing berwarna merah muda dan berbulu halus. Mahkota bunga (corolla) berbentuk memanjang, warna pangkal corolla putih dengan ujung corolla warna merah muda dan memiliki tangkai bunga yang pendek berukuran $2,3 \mathrm{~cm}$, berwarna coklat (Gambar 4b).

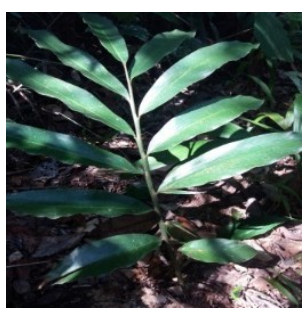

(a)

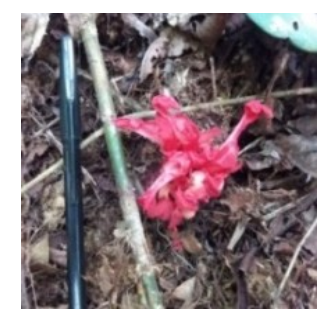

(b)
Gambar 4. Keseluruhan Etlingera nasuta (K. Schum.) R.M.Sm., (a). Batang dan daun, (b). Bunga

\section{Globba atrosanguinea Teijsm. \& Binn.}

G. atrosanguinea merupakan herba berumpun yang tumbuh di daerah yang lembab. $G$. atrosanguinea yang ditemukan memiliki tinggi 30 $\mathrm{cm}$, bentuk rimpang berdaging, berwarna putih, dengan aroma rimpang yang halus. Batang (pseudostem) memiliki permukaan yang berbulu dengan warna batang merah keunguan (Gambar 5a). Daun (lamina) memiliki permukaan kasar berbulu halus baik itu permukaan bawah maupun permukaan atas pada daun, bentuk daun lanset dengan ujung daun meruncing, pangkal daun membulat, pertulangan daun menyirip, dan tepi daun rata (Gambar 5a). Bunga (flos) terletak terminal atau berada diujung batang, ciri khasnya mempunyai warna bunga yang mencolok merah dan keorenan, tidak beraroma. Bunga tersusun majemuk dan mudah gugur bila disentuh (Gambar $5 b)$.

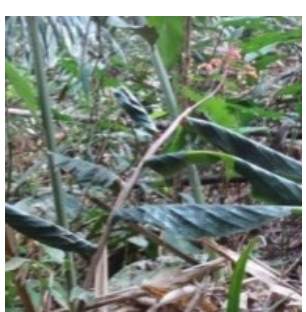

(a)

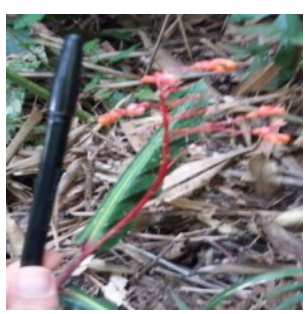

(b)
Gambar 5. Globba atrosanguinea Teijsm. \& Binn, (a). Keseluruhan $G$. atrosanguinea, (b). Bunga

\section{Hornstedia reticulata (K.Schum.) K.Schum.}

$H$. reticulata merupakan herba berumpun, memiliki tinggi $200 \mathrm{~cm}$. Rimpang berada di atas permukaan tanah, permukaan rimpang licin, membulat berwarna coklat, warna daging rimpang coklat, tidak beraroma. Jenis ini memiliki akar tunjang yang berwarna coklat kemerahan, dengan permukaannya berbulu halus. Batang (pseudostem) tegak secara horizontal, dengan permukaan batang kasap berwarna hijau kecoklatan (Gambar 6a). Daun (lamina) berbentuk memanjang dengan permukaan daun bagian atas licin, bagian permukaan bawah kasap, berwarna hijau, pertulangan 
daun menyirip, tepi daun rata, dan pangkal daun yang runcing (Gambar 6b). Bunga (flos) muncul dari rhizome dengan bunga berwarna merah dan berbentuk tabung dengan jarak yang rapat, terdiri dari 4-5 helaian mahkota bunga (corolla) yang memiliki panjang $4 \mathrm{~cm}$, jenis ini tumbuh pada daerah yang lembab (Gambar 6c).

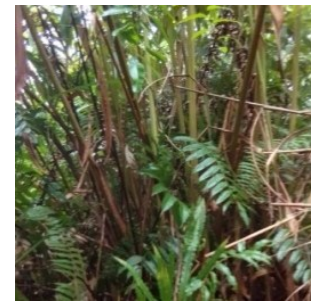

(a)

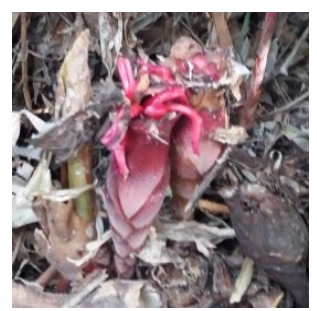

(c)

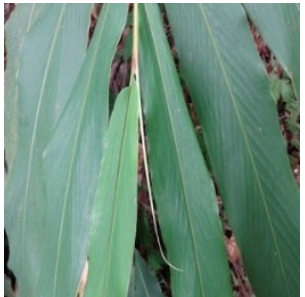

(b)

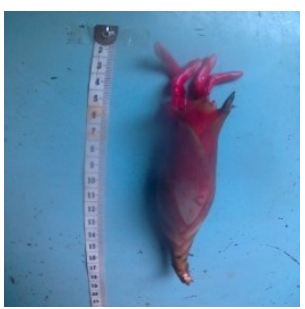

(d)
Gambar 6. Keseluruhan Hornstedia reticulata (K. Schum.) K. Schum., (a). Batang, (b). Daun, (c). Bunga, (d). Bakal buah

\section{Zingiber multibracteatum Holttum}

Z. multibracteatum merupakan herba berumpun yang memiliki tinggi tanaman 1-2 $\mathrm{m}$ dengan batang (pseudostem) yang tumbuh tegak memanjang secara horizontal, berwarna hijau, dengan permukaan batang licin (Gambar 7a). Bentuk rimpang berdaging, berwarna putih, dengan aroma yang halus. Daun (lamina) tunggal berselangseling, bentuk memanjang, permukaan atas daun licin dan bagian bawah kasap, pangkal daun meruncing, pertulangan daun menyirip, dan tepi daun rata (Gambar 7a).Bunga (flos) letaknya muncul langsung dari rimpang (rhizome), berwarna kuning kecoklatan. Warna bunga kuning pada awalnya dan menghasilkan bunga yang cokelat. Tangkai bunga yang panjang berwarna hijau kekuningaan, bunga berwarna kuning (Gambar 7b).

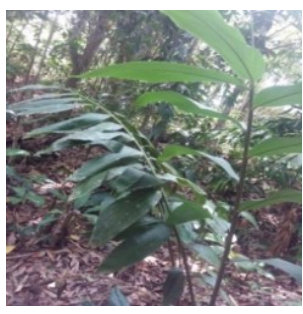

(a)

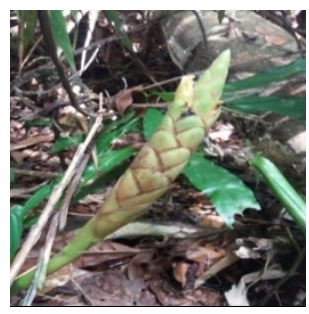

(b)
Gambar 7. Keseluruhan Zingiber multibracteatum Holttum, (a). batang dan daun, (b). bunga

\section{Zingiber zerumbet ( L.) Roscoe ex Sm.}

Z. zerumbet merupakan tumbuhan herba berumpun, batang (pseudostem) tegak memanjang secara horizontal dengan tinggi sekitar 1-2 meter, berwarna hijau. Rimpang (rhizome) berdaging, berwarna orange pucat dan beraroma tajam. Daun (lamina) tersusun berselang, bentuk daun memanjang, pertulangan daun menyirip, tepi daun rata (Gambar 8a). Bunga (flos) terletak aksilar atau muncul dari rhizome dengan berwarna kuning atau putih pucat. Bractea berbentuk bulat telur dengan panjang $10 \mathrm{~cm}$, berwarna hijau ketika masih muda dan menjadi merah ketika sudah tua berwarna merah (Gambar 8b).

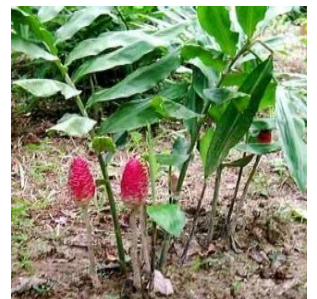

(a)

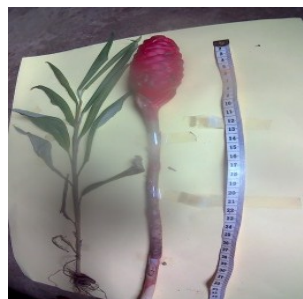

(b)
Gambar 8. Keseluruhan Zingiber zerumbet (L.) Roscoe ex Sm., (a). Daun dan Batang, (b). Bunga

\section{Pembahasan}

Jenis Zingiberaceae yang paling banyak ditemukan adalah dari genus Etlingera yang terdiri dari 3 jenis, sedangkan jenis yang paling sedikit ditemukan adalah dari genus Globba dan Hornstedia yang masing-masing hanya ditemukan satu jenis. Zingiberaceae yang ditemukan di kawasan hutan tembawang Desa Sumber Karya sebagaimana tertera pada Tabel 1 masih tergolong sedikit dari ha-sil penelitian menunjukkan bahwa spesies yang ditemukan sebanyak empat genus dari tujuh spe-sies dengan jumlah total individu sebanyak 57 individu, jika dibandingkan dengan penelitian Zingiberaceae di Kawasan Hutan Lindung Gunung Bawang, Kabupaten Bengkayang oleh Sepito et al. (2019) yang dimana ditemukan enam genus dari 17 spesies dengan jumlah individu se-banyak 81 individu. Perbedaan jumlah Zingiberaceae yang diperoleh di dua lokasi penelitian yang berbeda tersebut salah satunya disebabkan oleh perbedaan faktor fisik lingkungan, yaitu letak topografi, suhu dan kelembaban dua kawasan. Hal ini sesuai dengan pendapat Pandey (2003) yang menyatakan bahwa Zingiberaceae dapat hidup dari dataran rendah sampai ketinggian $2000 \mathrm{~m}$ dpl terutama di daerah dengan curah hujan yang tinggi. 
Berdasarkan hasil penelitian (Tabel 1) yang dilakukan di kawasan Hutan Tembawang Desa Sumber Karya, diketahui bahwa spesies Zingiberaceae yang paling banyak ditemukan dalam penelitian ini terdapat pada genus Etlingera, ini dikarenakan banyak ditemukan di areal terbuka atau hutan sekunder dan tumbuh secara mengelompok di tempat yang lembab. Hal ini sesuai dengan Larsen et al. (1999) dalam Nurainas \& Yunaidi (2007) yang menyatakan bahwa secara alami Etlingera tumbuh mengelompok di tempat-tempat yang lembab dengan vegetasi yang cukup rapat yang mana bisa tumbuh dengan cepat seperti gulma. Etlingera merupakan salah satu genus yang tumbuh pada hutan sekunder atau hutan yang baru terbuka dan beberapa spesies dari genus Etlingera dapat dijadikan indikator kerusakan habitat.

Genus Etlingera yang ditemukan dalam penelitian terdiri dari tiga jenis yaitu Etlingera coccinea, Etlingera elatior, dan Etlingera nasuta. Spesies Etlingera elatior ditemukan di tiga kawasan hutan tembawang dengan masing-masing terdiri dari dua individu. Penyebaran Etlingera elatior ada pada tiga lokasi tersebut dapat terjadi karena bantuan hewan pemakan buah, buah pada Etlingera elatior memiliki warna yang menarik. Menurut Kato et al. dan Sakai et al. dalam Poulsen (2006), menyatakan bahwa polinasi Elingera di Sumatera dan Borneo dibantu oleh lebah atau burung madu dan buah dimakan oleh hewan pengerat. Warna buah Etlingera elatior ada dua variasi yaitu, warna merah keunguan dan kuning kecoklatan, buah masak Etlingera elatior berwarna merah muda dan biji warna hitam dan menurut Poulsen (2006) buah Etlingera elatior merupakan buah majemuk dan warna buah merah, merah muda dan hijau kekuningan.

Spesies Etlingera coccinea memiliki individu sebanyak 9 individu, tetapi hanya terdapat di dua kawasan hutan tembawang yaitu tembawang Sibo dan tembawang beringin. Spesies Etlingera nasuta memiliki individu yang sedikit diantara genus Etlingera yang ditemukan, yaitu hanya 4 individu, dan hanya terdapat di kawasan hutan tembawang beringin. Etlingera coccinea dan Etlingera nasuta memiliki ciri khas bunga yang tenggelam sebagian di bawah permukaan tanah, pada penelitian dilapangan tidak ditemukan adanya buah dan penyebarannya tidak merata ada disetiap kawasan hutan tembawang. Menurut Dumbois dan Ellenberg (1974) menyatakan bahwa jenis yang memperbanyak diri dengan biji lebih luas penyebarannya jika dibandingkan dengan jenis tumbuhan yang alat reproduksinya menggunakan organ vegetatif.

Hasil yang diperoleh menunjukkan ada beberapa genus yang memiliki satu jenis saja yaitu Globba dan Hornstetia, hal ini disebabkan karena spesies dalam genus tersebut memiliki kemampuan yang berbeda dibandingkan dengan genus lain untuk hidup dan berkembang dalam suatu kawasan dan dikarenakan jenis dalam genus ini perlu cahaya matahari yang cukup dibanding jenis lainnya. Loveless (1989) menyatakan bahwa suatu tumbuhan dapat tumbuh dan berkembang biak dengan baik jika kebutuhan fisiologinya terpenuhi dan lingkungan yang menyediakannya. Oleh karena itu, setiap tumbuhan mempunyai suatu kisaran toleran tertentu terhadap kondisi sekitarnya.

Genus Globba yang ditemukan yaitu dari spesies Globba atrosanguinea dengan jumlah individu sebanyak tiga individu terdapat di kawasan hutan tembawang Beringin dan dijumpai pada daerah lembab di pinggiran sungai. Menurut Van Valkenburg \& Bunyapraphatsara (2002) menyatakan bahwa genus ini dapat tumbuh dari daerah rendah sampai daerah yang cukup tinggi, tetapi jenis ini lebih banyak ditemukan di daerah yang cukup ternaungi dan disepanjang daerah pinggiran sungai. Ciri umum untuk mengenal genus ini adalah letak dari perbungaannya terminal yang muncul langsung dari ujung batang dan bunganya yang berbentuk seperti sebuah anak panah. Menurut Poulsen (2006) jenis ini memiliki tinggi 0,5 meter, warna bawah daun pada saat masih muda berwarna keunguan, bunga agak mencolok dengan bunga kuning keorenan.

Genus Hornstedtia yang ditemukan yaitu Hornstedtia reticulata dengan jumlah individu sebanyak 18 individu yang terdapat di tiga kawasan hutan tembawang. Hal ini dikarenakan Hornstedtia reticulata ini dijumpai pada daerah dengan kelembaban 73.6-82.0\%, jenis ini juga sering djumpai dalam keadaan rusak karena dimakan oleh hewan. Menurut Whitmore (1984) menyatakan bahwa penyebaran yang luas dapat dipengaruhi oleh faktor lingkungan, alat reproduksi, interaksi beberapa jenis dan kompetisi. Ciri khas dari genus Hornstedtia, yaitu pembungaan yang berbentuk kumparan dilapisi oleh bractea yang kompak menjadi pembeda dengan genus lainnya dan memiliki akar tunjang yang berada di atas permukaan tanah, karakter ini merupakan ciri khas yang jelas dari genus ini. 
Genus Zingiber terdiri dari dua spesies yaitu Zingiber multibracteatum dan Zingiber zerumbet. Jenis Zingiber multibracteatum hanya ditemukan di kawasan hutan tembawang Beringin dengan individu sebanyak lima individu, sedangkan jenis Zingiber zerumbet ditemukan di dua kawasan hutan tembawang yaitu hutan tembawang Sibo dan hutan tembawang Nameng dengan jumlah individu sebanyak delapan individu. Zingiber multibracteatum dan Zingiber zerumbet ini.Penyebarannya tidak merata ada di tiga lokasi hutan tembawang Desa Sumber Karya, hal ini karena faktor lingkungan yang berbeda pada tiap kawasan hutan (Tabel 2). Selain itu, bunga juga dapat mempengaruhi dalam penyebaran genus Zingiber. Hal ini sesuai dengan pendapat menurut Nurainas dan Yunaidi (2007) yang menyatakan bahwa tempat tumbuh yang disenangi tumbuhan ini umumnya tempat-tempat lembab tapi beberapa jenis ada yang ditemukan pada hutan sekunder, hutan yang terbuka, pinggir sungai, dan kadang dapat tumbuh pada daerah terbuka dengan cahaya matahari penuh. Menurut Holtum (1950) yang menyatakan bahwa bunga Zingiber umurnya pendek dan bunga mekar pada pagi hari setelah itu menutup dalam beberapa jam. Selain itu, bunga Zingiber juga cepat mengalami kerusakan sehingga memungkinkan penyebaran Zingiber jarang terjadi sehingga jenis yang diperoleh di penelitian sedikit.

Karakter umum pada genus Zingiber yaitu bunga yang mudah rapuh, berbentuk tanduk. Menurut Kress et al. (2002) menyatakan bahwa genus Zingiber mudah dikenali dari bentuk bunga yang berbentuk tanduk. Menurut Nalawade et al. (2003) bunga kuning atau putih pucat, yang biasanya lebih panjang dari pada braktea, rapuh, dan hanya bertahan beberapa jam dan muncul dari braktea paling rendah terlebih dahulu, dan ketika habis bunga mengering dan jatuh.

\section{DAFTAR PUSTAKA}

Dumbois, D \& Ellenberg, H, 1974, Aims and Methods of Vegetation Ecology, Wiley, New York

Harum, F, 2012, Manual Pelatihan: Pengelolaan Sumber Daya Alam untuk Masyarakat Perdesaan, Jakarta (ID): PNPM Lingkungan Mandiri Pedesaan (PNPM-LMP)

Holtum, RE, 1950, The Zingiberaceae of The Malay Peninsular, Gardens, Bulletin, Singapore

Kress, WJ, Prince, LM, \& Williams, KJ, 2002, The phylogeny and a new classification of the gingers (Zingiberaceae): Evidence from molecular data, Jurnal Botany, vol. 89, no. 11, hal. 1682-1696
Lamb, A, Gobilik, J, Ardiyanti, M \& Poulsen, AD, 2013, A Guide To Gingers Of Borneo, Natural History Publication, Kinabalu

Larsen, K, Ibrahim, H, Khaw, SH \& Saw, LG, 1999, Gingers of Peninsular Malaysia and Singapore. Natural History Publication, Kinabalu

Loveless, AR, 1989, Prinsip-Prinsip Biologi Tumbuhan Untuk Daerah Tropik, PT Gramedia, Jakarta

Nalawade, SM., Sagare, AP., Lee, CY., Kao, CL., \& Tsay, HS, 2003, Studies on tissue culture of Chinese medicinal plant resources in Taiwan and their sustainable utilization. Journal Botanical Bulletin Academia Sinica, vol.31, no.1, hal.79-98

Nurainas \& Yunaidi, 2007, Panduan Lapangan Jahejahean Liar di Taman Nasional Sibert, Garisastra, Padang

Onrizal, 2005, Adaptasi Tumbuhan Mangrove Pada Lingkungan Salin dan Jenuh air, Jurnal Biologi, vol.4, no.6, hal 359-372

Pandey, BP, 2003, A Textbook of Botany: Angiosperm First Edition, S Chand and Company, Ram Nagar, New Delhi, India

Poulsen, AD, 2006, Gingers of Sarawak, Natural History Publication, Kota Kinabalu

Rugayah, Elizabeth, Widjaja \& Praptiwi, 2004, Pedoman Pengumpulan Data Keaneragaman Flora, Pusat Penelitian Biologi - Lembaga Ilmu Pengetahuan Indonesia, Bogor

Sepito, B, Fernando, T \& Masitoh, S, 2019, Identifikasi Jahe-jahean (Zingiberaceae) di Kawasan Hutan Lindung Gunung Bawang Kabupaten Bengkayang Kalimantan Barat, Jurnal Hutan Lestari, vol.7, no.1, hal.62-68

Steenis, 2005, Buah Bit (Beta Vulgaris), Penerbit PT Gramedia Pustaka Utama, Jakarta

Van Valkenburg \& Bunyaphatsara, N, 2002, Plant Resources of South-East Asia Vegetable oils and fats, Bogor, Indonesia

Whitmore, TC, 1984, Tropical Rain Forests Of The Far East, Second Edition, Oxford University Press, Oxford 